\title{
The nematophagous fungus Verticillium chlamydosporium produces a chymoelastase- like protease which hydrolyses host nematode proteins in situ
}

\author{
Rudi Segers, ${ }^{1}$ Tariq M. Butt, ${ }^{1}$ Brian R. Kerry ${ }^{1}$ and John F. Peberdy ${ }^{2}$ \\ Author for correspondence: Rudi Segers. Tel: +44582 763133. Fax: + 44582760981. \\ e-mail: SEGERSR@BBSRC.AC.UK
}

1 Rothamsted Experimental Station, Entomology \& Nematology Department, Harpenden, Hertfordshire AL5 2JQ, UK

2 Department of Life Sciences, University of Nottingham, University Park, Nottingham NG7 2RD, UK

\begin{abstract}
The nematophagous fungus Verticillium chlamydosporium secreted several proteases in submerged culture in which soya peptone was the sole carbon and nitrogen source. One protease, VCP1 $(M, 33000, \mathrm{pl} 10.2)$, was purified 14-fold from culture filtrates to apparent homogeneity using preparative isoelectric focusing in free solution, and shown to rapidly hydrolyse the chymotrypsin substrate Suc-(Ala) ${ }_{2}$-Pro-Phe-pNA and elastin. VCP1 had a $K_{m}$ for Suc-(Ala) ${ }_{2}$-Pro-Phe-pNA of $4.3 \times 10^{-5} \mathrm{M}$ and a $k_{\text {cat }}$ of $5.8 \mathrm{~s}^{-1}$. It was highly sensitive to PMSF and TPCK, but only moderately sensitive to chicken egg-white and soya bean trypsin inhibitors. VCP1 degraded a wide range of polymeric substrates, including Azocoll, hide protein, elastin, casein and albumin, and accounted for most of the non-specific protease activity detected in culture filtrates. The purified enzyme hydrolysed proteins in situ from the outer layer of the egg shell of the host nematode Meloidogyne incognita and exposed its chitin layer. VCP1 was secreted by several isolates of $V$. chlamydosporium and $V$. lecanii, pathogens of nematodes and insects respectively, but not plantpathogenic species of Verticillium. These observations suggest that VCP1 or similar enzyme(s) may play a role in the infection of invertebrates.
\end{abstract}

Keywords: Chymotrypsin, chymoelastase, protease, nematophagous fungus, Verticillium chlamydosporium

\section{INTRODUCTION}

The hyphomycete fungus Verticillium chlamydosporium is a widespread pathogen of eggs and females of root-knot and cyst nematodes (Willcox \& Tribe, 1974; Kerry \& Crump, 1977; Morgan-Jones et al., 1981). It plays an important role in the suppression of populations of Heterodera avenae in cereal monocultures (Kerry et al., 1982). There is considerable interest in developing this fungus for control of nematodes in the field because it offers an environmentally benign alternative to chemical pesticides. Although some aspects of its ecology (De Leij,

\footnotetext{
Abbreviations: $B z$, benzoyl; $C B Z$, carboxybenzoxy; CEW, chicken eggwhite inhibitor, containing ovoinhibitor; E-64, trans-epoxysuccinyl-Lleucylamido-(4-guanidino) butane; MeOSuc, methoxysuccinyl; PMSF, phenylmethylsulphonyl fluoride; PNA, $p$-nitroanilide; STI, soybean trypsin inhibitor; Suc, $N$-succinyl; TEW, turkey egg-white inhibitor; TLCK, tosyl-Lyschloromethyl ketone; TPCK, tosyl-Phe-chloromethyl ketone; VCP1, chymoelastase-like protease from $V$. chlamydosporium.
}

1992) and taxonomy (Carder et al., 1993) have been elucidated, its mode of action remains largely obscure (Morgan-Jones et al., 1983). Successful exploitation of this fungus will, however, depend on a comprehensive understanding of its biology, in particular identification of those attributes which determine virulence.

Enzymes play a key role in fungal infection processes (Butt, 1990). Lipases (Paris \& Ferron, 1979), chitinases (Jackson et al., 1985) and proteases are considered to be virulence determinants of entomogenous fungi. The protease chymoelastase ( $\operatorname{Pr} 1)$, a major protein secreted by Metarbizium anisopliae and other hyphomycete fungi ( $\mathrm{St}$ Leger et al., 1987b), has been shown to be a key enzyme in the infection process (St Leger et al., 1988). Proteases are also virulence determinants of the human-pathogenic fungi Candida albicans (Kwon-Chung et al., 1985) and Aspergillus fumigatus (Frosco et al., 1992). Little is known about the enzymes secreted by egg-parasitic nematophagous fungi but proteases may be important in host 
infection because a large part of the host egg shell and cuticle is composed of protein (Clarke et al., 1967; Bird \& McClure, 1976; Perry \& Trett, 1986).

Proteolytic activity has been demonstrated for $V$. cblamydosporium (Kunert et al., 1987; Carder et al., 1993) and $V$. suchlasporium (Dackman et al., 1989; Dackman, 1990), a closely related species with disputed taxonomic status (Carder et al., 1993). Lopez-Llorca (1990) purified a $32 \mathrm{kDa}$ serine protease from culture filtrates of $V$. suchlasporium and demonstrated that it was secreted during infection of cyst nematode eggs (Lopez-Llorca \& Robertson, 1992). This paper describes the properties ard possible role of a major protease secreted by an isolate of $V$. chlamydosporium which could be used in the selection of virulent strains of fungi for use in biocontrol programmes.

\section{METHODS}

Organisms and growth conditions. The fungi used in this study included five isolates of the nematophagous fungus Verticillium chlamydosporium $(V c 8, V c 10, V c 11, V c 26, V c 65$, three isolates of the entomophagous fungus $V$. lecanii ( $V / 4$, $V l G, V l M y)$ and one isolate each of the plant pathogens $V$. alboatrum $(V a)$ and $V$. dabliae $(V d)$. All the $V$. chlamydosporium isolates were originally collected from infected nematode egg:; or from nematode-suppressive soils, and stored on silica gel ar: $4{ }^{\circ} \mathrm{C}$ in the Rothamsted culture collection. Isolate $V l G$ (origina name $A \ln 3$ ) was a gift of Dr G. Moritz (Martin-Luther University, Halle, Germany), VI4 and VlMy (Mycotal $\left.{ }^{\circledR}\right)$ were obtained from Chr. Hansen's BioSystems (Denmark), and Koppert (the Netherlands) respectively. The plant-pathogenic isolates $V$. albo-atrum 1974 and $V$. dabliae 327, isolated from hop and strawberry, respectively, were gifts from Dr D. J. Barbara (East Malling, UK). All the isolates were maintained on potato dextrose agar at $23^{\circ} \mathrm{C}$ in the dark.

Conidia and/or chlamydospores, harvested in sterile distilled water from 3-week-old cultures, were used to inoculate soya peptone medium (SPM: $10 \mathrm{~g}$ soya peptone, $0.3 \mathrm{~g} \mathrm{~K} \mathrm{KPO}_{4}$, $0.3 \mathrm{~g} \mathrm{MgSO}_{4} .7 \mathrm{H}_{2} \mathrm{O}, 0.15 \mathrm{~g} \mathrm{NaCl}, 0.3 \mathrm{~g} \mathrm{CaCl}_{2} \cdot 6 \mathrm{H}_{2} \mathrm{O}, 0.8 \mathrm{mg}$ $\mathrm{MnSO}_{4} \cdot 6 \mathrm{H}_{2} \mathrm{O}, 0.2 \mathrm{mg} \mathrm{CuSO}{ }_{4} \cdot 5 \mathrm{H}_{2} \mathrm{O}$, and $2 \mathrm{mg} \mathrm{FeSO}_{4} \cdot 7 \mathrm{H}_{2} \mathrm{O}$, made up to 11 with distilled water). The final concentration of the inoculum was $10^{5}$ conidia $\mathrm{ml}^{-1}$ and $3 \times 10^{3}$ chlamydospores $\mathrm{ml}^{-1}$. Studies were done using $250 \mathrm{ml}$ conical flasks containing $150 \mathrm{ml}$ SPM. Isolate $V c 10$ was also grown in four 21 flasks each containing $11 \mathrm{SPM}$. The flasks were incubated at $23^{\circ} \mathrm{C}$ in a Gallenkamp orbital shaker ( 90 r.p.m.) in the dark for $7 \mathrm{~d}$.

Comparative studies were done using the entomogenous fungus Metarbizium anisopliae (V245) originally isolated from Finnish soil and maintained on Sabouraud dextrose agar at $23{ }^{\circ} \mathrm{C}$ in darkness. Conidia from 2 -week-old cultures were harvested in an aqueous solution of Tween 80 and $1 \mathrm{ml}$ suspension containing $10^{7}$ conidia $\mathrm{ml}^{-1}$ was added to a medium $(100 \mathrm{ml})$ containing the same salts as SPM, but supplemented with beetle (Phaedon cocbleariae) homogenate $\left(10 \mathrm{mg} \mathrm{ml}^{-1}\right.$ ) (St Leger et al., 1986). Incubation was as with $V c 10$.

The root-knot nematode Meloidogyne incognita (Kofoid \& White) Chitwood was routinely maintained on Solanum melongena cv. Black Bell in greenhouse conditions $\left(26^{\circ} \mathrm{C}\right)$.

Chemicals. Most reagents were obtained from Sigma except for acrylamide (Protogel, National Diagnostics), neutralized soya peptone and Sabouraud dextrose agar (Oxoid), dialysis tubing (Medicell International), ammonium sulphate (Fisons), glycine $(\mathrm{BDH})$, molecular mass markers and bovine serum albumin
(Bio-Rad); ampholytes, GelBond and nitrocellulose were from Pharmacia.

Protein determination. Protein concentrations were determined by the method of Bradford (1976) using bovine serum albumin as a standard.

Preparation of crude enzyme concentrates. Cultures were harvested after $8 \mathrm{~d}$ by vacuum filtration through Whatman No. 1 filter paper on a Büchner funnel. Proteins were precipitated by adding solid ammonium sulphate to the culture filtrates $(80 \%$ saturation) and collected by centrifugation ( $10000 \mathrm{~g}$ for $30 \mathrm{~min})$. The pellet was resuspended in $0.05 \mathrm{M}$ Tris, $\mathrm{pH} \mathrm{7.9}$, and dialysed overnight at $4{ }^{\circ} \mathrm{C}$ against 300 volumes of buffer. This crude enzyme concentrate was used for further purification.

Preparative and analytical isoelectric focusing (IEF). Preparative IEF was done with a Bio-Rad Rotofor electrofocusing cell (Pichuantes et al., 1989; Huang et al., 1992). A mixture of $52 \mathrm{ml}$ enzyme concentrate, $2 \mathrm{ml}$ glycerol and $1 \cdot 1 \mathrm{ml}$ Pharmalyte 3-10 was injected in every other compartment of the focusing chamber. Ion exchange membranes were equilibrated and electrolyte solutions prepared according to the manufacturer's instructions. A ceramic cooling finger kept the sample at $4{ }^{\circ} \mathrm{C}$ during the whole run, which lasted $5 \mathrm{~h}$, during which time the voltage gradually increased from 400 to $960 \mathrm{~V}$. Twenty fractions were collected simultaneously under vacuum. The protein content, pI and proteolytic activity of each sample was determined. Maximum protease activity was recorded in the first five fractions (pI 8-10), which were pooled and refractionated using $2 \%(\mathrm{v} / \mathrm{v})$ ampholytes, $\mathrm{pH} 8-10 \cdot 5$.

Analytical IEF was done using a Pharmacia Multiphor II apparatus at $5{ }^{\circ} \mathrm{C}$ for $30 \mathrm{~min}$ according to the manufacturer's instructions. Samples $(20 \mu \mathrm{l})$ of culture filtrates and purified enzyme (i.e. fraction with highest activity) were applied alongside pI markers using paper strips to an ultrathin $5.4 \%$ (w/v) polyacrylamide gel containing $10 \%$ Pharmalyte 3-10.

Enzymoblotting. This was performed according to the method of Ohlsson $e t$ al. (1986) except that proteins from IEF gels were transferred to nitrocellulose by semi-dry electroblotting using the Novablot system (Pharmacia). The transfer buffer system used was as in Bjerrum \& Schafer-Nielsen (1986).

Electrophoresis. SDS-PAGE was done according to the method of Laemmli (1970) using a $1 \mathrm{~mm}$ thick gel $(12 \%$ resolving and $3.9 \%$ stacking gel). Following electrophoresis, proteins were incubated with Coomassie stain $(0.2 \%, \mathrm{w} / \mathrm{v}$, Coomassie Brilliant Blue R250 in destain) and destained using an aqueous mixture of $26 \%(\mathrm{v} / \mathrm{v})$ ethanol and $10 \%(\mathrm{v} / \mathrm{v})$ acetic acid.

Enzyme assays. Proteolytic activity of crude and purified enzymes was determined using a range of chromogenic substrates, including Azocoll, hide powder azure, elastin-Congo red, elastin-orcein, azocasein and azoalbumin. Each assay consisted of $500 \mu \mathrm{l}$ substrate $\left(10 \mathrm{mg} \mathrm{ml}^{-1}\right), 490 \mu \mathrm{l} 0 \cdot 1 \mathrm{M}$ Tris $\mathrm{pH} 7 \cdot 9$, and $10 \mu \mathrm{l}$ enzyme. Azocoll was prewashed according to the precautions outlined by Chavira et al. (1984). The mixture was incubated for $1 \mathrm{~h}$ on a rotary shaker at $37^{\circ} \mathrm{C}$, after which the protein was pelleted at 14000 r.p.m. in an Eppendorf microcentrifuge for $5 \mathrm{~min}$. Undigested azocasein and azoalbumin were precipitated by adding $200 \mu 120 \%$ (w/v) TCA, left to stand for $30 \mathrm{~min}$ then centrifuged in an Eppendorf microcentrifuge at 14000 r.p.m. for $5 \mathrm{~min}$. The absorbance of the supernatants was read using a Hewlett Packard diode array spectrophotometer $8452 \mathrm{~A}$ fitted with a temperature-controlled multicell unit at the following wavelengths: $520 \mathrm{~nm}$ (Azocoll), $595 \mathrm{~nm}$ (hide protein azure), $495 \mathrm{~nm}$ (elastin-Congo red), $592 \mathrm{~nm}$ (elastin-orcein), $336 \mathrm{~nm}$ (azocasein), and $326 \mathrm{~nm}$ (azoalbumin). Reference enzymes included final concentrations 

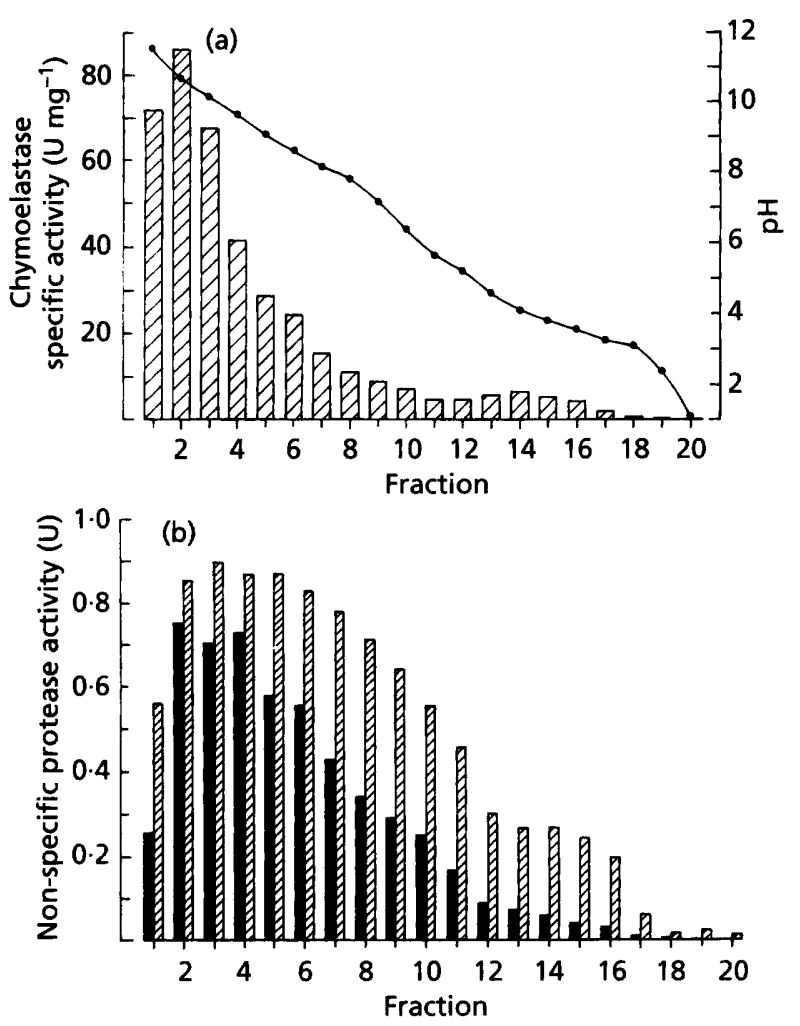

Fig. 1. (a) Chymoelastase activity measured using Suc-(Ala) $2_{2}^{-}$ Pro-Phe-pNA. o, pH of fractions. (b) Non-specific protease activity measured using Azocoll at $\mathrm{pH} 6(\boldsymbol{D})$ and $\mathrm{pH} 9$ (熘). Both activities were from fractions of crude enzyme concentrate separated by IEF using the Rotofor system (pH 3-10). One unit of activity for hydrolysis of Azocoll is defined as increase in $A_{520}$ of 1 absorbance unit $h^{-1}$.

of $0.01 \mathrm{mg}$ porcine pancreatic trypsin $\mathrm{ml}^{-1}, 0.01 \mathrm{mg}$ bovine pancreatic chymotrypsin $\mathrm{ml}^{-1}$ and 0.05 or $0.2 \mathrm{mg}$ porcine pancreatic elastase $\mathrm{ml}^{-1}$. For elastolytic activity, standard curves were prepared measuring the absorbance of dilutions of elastinCongo red that had been completely hydrolysed with porcine pancreatic elastase. One unit (U) of elastase activity is defined as the amount of enzyme that hydrolysed $1 \mathrm{mg}$ elastin in $3 \mathrm{~h}$ at $37^{\circ} \mathrm{C}$.

Spectrophotometric assays for specific enzymes were done using $p$-nitroanilide oligopeptides as substrates. Crude and purified enzyme samples $(10 \mu \mathrm{l})$ were added to $490 \mu \mathrm{l} 0 \cdot 1 \mathrm{M}$ Tris/ $\mathrm{HCl}$ buffer, $\mathrm{pH} 7 \cdot 9$, and the reaction, which was started by adding $500 \mu$ l substrate ( $2 \mathrm{mM}$ in the same buffer), was followed by continuous recording of the increase in absorbance at $410 \mathrm{~nm}$, at $37^{\circ} \mathrm{C}$. Chymotrypsin-like activity was assayed using Suc-(Ala) ${ }_{2}$-Pro-Phe-pNA (Del Mar et al., 1979), Suc-Phe-pNA (Nagel et al., 1965) and Bz-Tyr-pNA (Bundy, 1962). Trypsinlike activity was assayed using Bz-Arg-pNA (Erlanger et al., 1961) and Bz-Phe-Val-Arg-pNA (Svendsen et al., 1972), while Suc-(Ala) $)_{3}$-pNA (Bieth et al., 1974) and MeOSuc-(Ala) ${ }_{2}$-ProVal-pNA (Nakajima et al., 1979) were used to detect elastase-like activity. Subtilisin-like activity was tested with $\mathrm{CBZ}-(\mathrm{Ala})_{2}$ Leu-pNA (Stepanov et al., 1977). One unit of activity is defined as the amount of enzyme releasing $1 \mu \mathrm{mol} p$-nitroaniline $\mathrm{min}^{-1}$. The absorption coefficient was $10700 \mathrm{M}^{-1} \mathrm{~cm}^{-1}$ at $410 \mathrm{~nm}$.

Inhibition studies. Protease inhibitors (see Table 4) were used to characterize the purified enzyme and proteases in culture filtrates. Samples $(10 \mu \mathrm{l})$ were preincubated with inhibitor at room temperature for $1 \mathrm{~h}$ before addition of $500 \mu \mathrm{l} 2 \mathrm{mM}$ Suc(Ala) $)_{2}$-Pro-Phe-pNA and buffer to make a final volume of $1 \mathrm{ml}$. Appropriate solvent controls were included.

Determination of kinetic constants. $K_{\mathrm{m}}$ and $V_{\max }$ values for Suc-(Ala) ${ }_{2}$-Pro-Phe-pNA were determined using an iterative least-squares fit to the Michaelis-Menten equation (Leatherbarrow, 1990). Catalytic constant $\left(k_{\text {cat }}\right)$ and specificity constant $\left(k_{\text {cat }} / K_{\mathrm{m}}\right)$ were calculated assuming that there was one active site per enzyme unit and that $V_{\max }=k_{\text {cat }} \times[\mathrm{E}]$, where [E] is the concentration of active sites. Duplicate measurements were made at eight substrate levels between 0.06 and 12 times $K_{\mathrm{m}}$.

Proteolysis of $\boldsymbol{M}$. incognita egg shells. Nematode eggs were collected by washing the roots of plants that had well-developed root-knots in $20 \%(\mathrm{v} / \mathrm{v})$ domestic bleach (Teepol; available chlorine $4 \%, \mathrm{w} / \mathrm{v}$ ), then immediately rinsed on a $30 \mu \mathrm{m}$ mesh sieve. After separating eggs and debris by sugar centrifugation $\left(47 \%, w / v\right.$, sucrose), eggs were sterilized in $0.1 \% \mathrm{HgCl}_{2}$ (Sijmons et al., 1991). The effect of VCP1 on the egg shell was assessed by incubating 7500 eggs with $0 \cdot 2 \mathrm{UVCP} 1$ at $23^{\circ} \mathrm{C}$ for $48 \mathrm{~h}$; enzyme that had been denatured by boiling for $5 \mathrm{~min}$

\section{Table 1. Scheme for the purification of VCP1 from V. chlamydosporium}

One unit $(\mathrm{U})$ of chymoelastase activity is the amount of enzyme required to catalyse the production of $1 \mu \mathrm{mol} p$-nitroaniline from Suc-(Ala $)_{2}$-Pro-Phe-pNA $\mathrm{min}^{-1}$.

\begin{tabular}{|c|c|c|c|c|c|}
\hline $\begin{array}{l}\text { Purification } \\
\text { procedure }\end{array}$ & $\begin{array}{l}\text { Total } \\
\text { activity } \\
\text { (U) }\end{array}$ & $\begin{array}{c}\text { Yield } \\
(\%)\end{array}$ & $\begin{array}{c}\text { Total } \\
\text { protein } \\
\text { (mg) }\end{array}$ & $\begin{array}{c}\text { Specific } \\
\text { activity } \\
\text { (units } \\
\mathrm{mg}^{-1} \text { ) }\end{array}$ & $\begin{array}{c}\text { Purification } \\
\text { factor }\end{array}$ \\
\hline Crude filtrate & $4889 \cdot 5$ & 100 & $285 \cdot 1$ & $17 \cdot 2$ & $1 \cdot 0$ \\
\hline $\begin{array}{l}\text { Ammonium sulphate } \\
\text { precipitation }\end{array}$ & $2053 \cdot 6$ & 42 & $70 \cdot 3$ & $29 \cdot 2$ & $1 \cdot 7$ \\
\hline Isoelectric focusing & $286 \cdot 7$ & $5 \cdot 9$ & $2 \cdot 2$ & $130 \cdot 3$ & $7 \cdot 6$ \\
\hline $\begin{array}{l}\text { Isoelectric focusing }+ \\
\text { refractionation }\end{array}$ & $126 \cdot 9$ & $2 \cdot 6$ & $0 \cdot 5$ & $233 \cdot 2$ & $13 \cdot 6$ \\
\hline
\end{tabular}




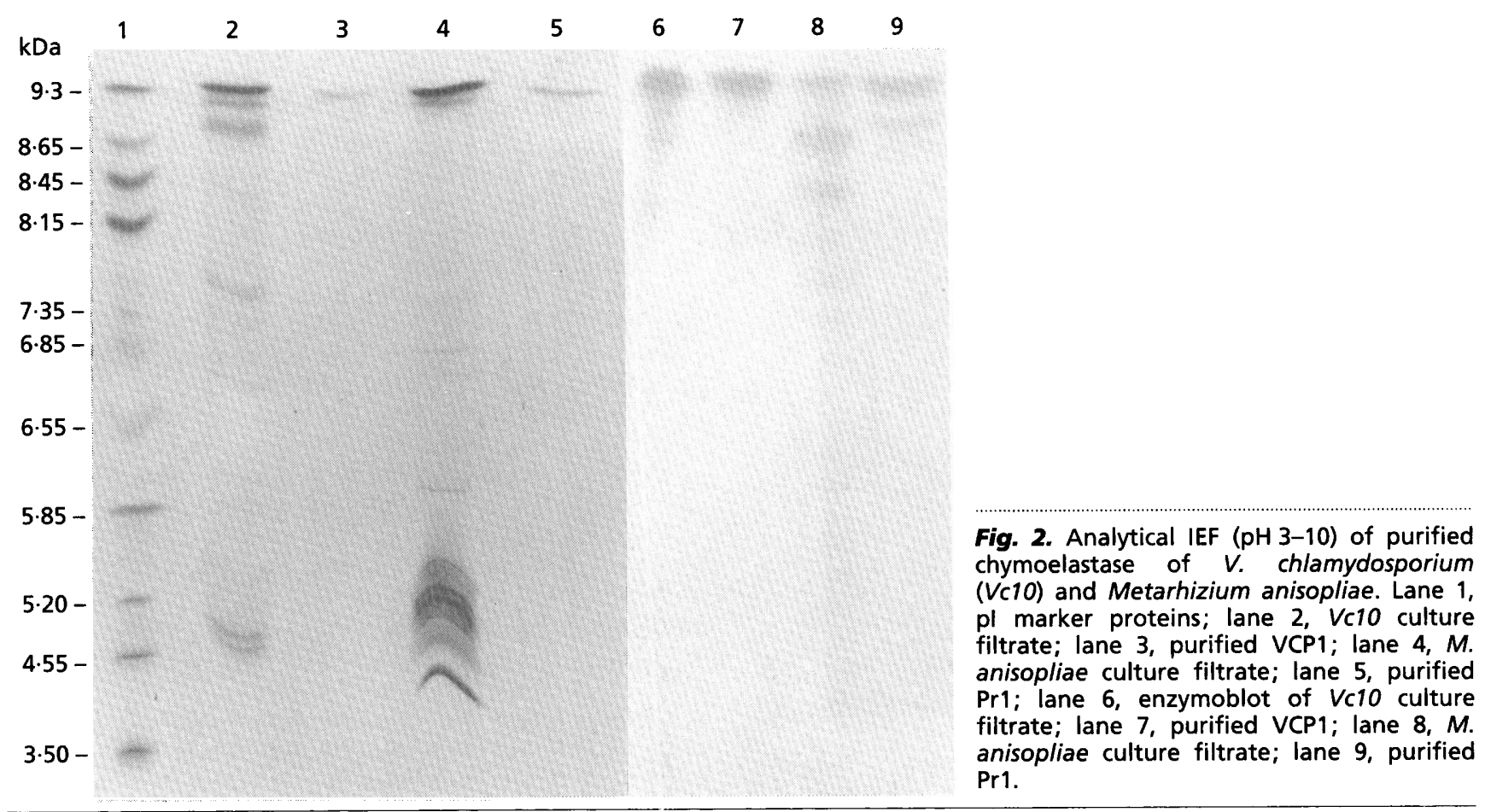

served as a control. There were three replicates in both the control and enzyme treatments. Eggs were pelleted at 10000 r.p.m. in an Eppendorf microcentrifuge for $1 \mathrm{~min}$, after which the protein content of the supernatant was determined (Bradford, 1976). Similarly treated eggs were stained for $\beta$ glucans with Calcofluor white M2R (Butt et al., 1989) after $18 \mathrm{~h}$ incubation and examined with an Olympus BH-2 microscope fitted with epifluorescence attachments, including a $405 \mathrm{~nm}$ excitation filter and a $455 \mathrm{~nm}$ barrier filter. Photomicrographs of representative specimens were recorded on Ilford XP2 400 ASA film.

Unless stated otherwise, all experiments were at least duplicated. Purification steps were performed at least five times. Data are reported for a representative purification scheme.

\section{RESULTS}

\section{Electrophoretic analyses}

Protease activities present in enzyme concentrates prepared from culture filtrates of $V$. chlamydosporium were analysed using preparative isoelectric focusing in the Rotofor system. All the IEF fractions contained chymotrypsin-like and non-specific protease activity, against Suc-(Ala) $)_{2}$-Pro-Phe-pNA and Azocoll, respectively, but these were greatest at pI 8-10 (Fig. 1). Chymotrypsin-like activity appeared to account for most of the non-specific protease activity in the alkaline fractions; however, the presence of non-chymotrypsinlike enzymes with intermediate $\mathrm{pI}$ values in the culture filtrate cannot be ruled out. Greater activity was measured at pH 9 in every fraction (Fig. 1b). The alkaline fractions were refocused using narrow-range ampholytes ( $\mathrm{pH}$ 8-10.5), which resulted in a 14-fold enrichment of the chymotrypsin-like enzyme, VCP1 (Table 1). Both IEF of purified (V) $V$. chlamydosporium

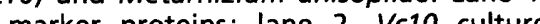
filtrate; lane 3 , purified VCP1; lane 4, $M$. anisopliae culture filtrate; lane 5 , purified Pr1; lane 6, enzymoblot of Vc10 culture filtrate; lane 7 , purified VCP1; lane $8, M$. anisopliae culture filtrate; lane 9, purified Pri. 
Table 2. Substrate specificity of purified VCP1 and culture filtrates from Vc10, and reference proteases

All data are means of duplicate assays.

\begin{tabular}{|c|c|c|c|c|c|}
\hline \multirow[t]{2}{*}{ Substrate } & \multicolumn{5}{|c|}{ Activity (\% of max. specific activity) of: } \\
\hline & $\begin{array}{c}V c 10 \\
\text { VCP1 }\end{array}$ & $\begin{array}{c}V c 10 \\
\text { filtrate }\end{array}$ & Trypsin & $\begin{array}{l}\text { Chymo- } \\
\text { trypsin }\end{array}$ & Elastase \\
\hline Suc-(Ala $)_{2}$-Pro-Phe-pNA & 100 & 100 & $15 \cdot 8$ & 100 & 100 \\
\hline Suc-Phe-pNA & $0 \cdot 1$ & 0 & 0 & 0 & 0 \\
\hline Bz-Tyr-pNA & 0 & 0 & 0 & 0 & 0 \\
\hline Bz-Arg-pNA & 0 & $0 \cdot 1$ & $1 \cdot 0$ & 0 & 0 \\
\hline Bz-Phe-Val-Arg-pNA & $8 \cdot 3$ & $5 \cdot 5$ & 100 & $0 \cdot 2$ & $0 \cdot 5$ \\
\hline Suc- $(\mathrm{Ala})_{3}-\mathrm{pNA}$ & $0 \cdot 2$ & $0 \cdot 6$ & 0 & 0 & $21 \cdot 3$ \\
\hline MeOSuc-(Ala $)_{2}$-Pro-Val-pNA & 0 & $0 \cdot 1$ & $0 \cdot 1$ & 0 & $8 \cdot 5$ \\
\hline $\mathrm{CBZ}-(\mathrm{Ala})_{2}$-Leu-pNA & $0 \cdot 4$ & $0 \cdot 2$ & 0 & 0 & 0 \\
\hline Max. specific activity $\left(\mathrm{U} \mathrm{mg}^{-1}\right)$ & $19 \cdot 2$ & $13 \cdot 2$ & $7 \cdot 1$ & $53 \cdot 6$ & $0 \cdot 3$ \\
\hline
\end{tabular}

Table 3. Substrate utilization of purified VCP1 and culture filtrates of Vc10

Activities are expressed as percentage of maximum specific activity per substrate. One unit of specific activity for hydrolysis of the following substrates is defined as follows. Azocoll hydrolysis, increase in $A_{520}$ of 1 absorbance unit $\mathrm{mg}^{-1} \mathrm{~min}^{-1}$; hide protein azure hydrolysis, increase in $A_{595}$ of 1 absorbance unit $\mathrm{mg}^{-1} \mathrm{~min}^{-1}$; elastin-Congo red hydrolysis, 1 unit of elastolytic activity solubilizes $1 \mathrm{mg}$ elastin in $3 \mathrm{~h}$ at $37^{\circ} \mathrm{C}$; elastin-orcein hydrolysis: increase in $A_{592}$ of 1 absorbance unit $\mathrm{mg}^{-1} \mathrm{~h}^{-1}$; azocasein hydrolysis, increase in $A_{336}$ of 1 absorbance unit $\mathrm{mg}^{-1} \mathrm{~min}^{-1}$; azoalbumin hydrolysis, increase in $A_{326}$ of 1 absorbance unit $\mathrm{mg}^{-1} \mathrm{ml}^{-1}$. All data are means of duplicate assays.

\begin{tabular}{|c|c|c|c|c|c|c|}
\hline \multirow[t]{2}{*}{ Enzyme } & \multicolumn{6}{|c|}{ Activity (\% of max. specific activity) using: } \\
\hline & Azocoll & $\begin{array}{c}\text { Hide } \\
\text { protein } \\
\text { azure }\end{array}$ & $\begin{array}{c}\text { Elastin- } \\
\text { congo } \\
\text { red }\end{array}$ & $\begin{array}{l}\text { Elastin- } \\
\text { orcein }\end{array}$ & Azocasein & Azoalbumin \\
\hline VCP1 & 100 & 100 & $36 \cdot 3$ & $80 \cdot 2$ & $88 \cdot 8$ & $53 \cdot 3$ \\
\hline Culture filtrate & $29 \cdot 3$ & $18 \cdot 4$ & $27 \cdot 2$ & $24 \cdot 3$ & 100 & 100 \\
\hline Trypsin $\left(0.01 \mathrm{mg} \mathrm{ml}^{-1}\right)$ & $30 \cdot 9$ & $14 \cdot 8$ & $2 \cdot 6$ & $3 \cdot 8$ & $55 \cdot 9$ & $26 \cdot 6$ \\
\hline $\begin{array}{l}\text { Chymotrypsin } \\
\left(0.01 \mathrm{mg} \mathrm{ml}^{-1}\right)\end{array}$ & $18 \cdot 4$ & $14 \cdot 2$ & $1 \cdot 7$ & $10 \cdot 3$ & $67 \cdot 2$ & $34 \cdot 9$ \\
\hline Elastase $\left(0.05 \mathrm{mg} \mathrm{ml}^{-1}\right)$ & $16 \cdot 4$ & $11 \cdot 3$ & $5 \cdot 3$ & $12 \cdot 9$ & $27 \cdot 5$ & $13 \cdot 1$ \\
\hline Elastase $\left(0 \cdot 2 \mathrm{mg} \mathrm{ml}^{-1}\right)$ & $31 \cdot 3$ & $10 \cdot 2$ & 100 & 100 & $88 \cdot 7$ & $81 \cdot 2$ \\
\hline $\begin{array}{l}\text { Max. specific activity } \\
\left(\mathrm{U} \mathrm{mg}^{-1}\right)\end{array}$ & $5 \cdot 0$ & $16 \cdot 6$ & $6 \cdot 2$ & $5 \cdot 6$ & $4 \cdot 2$ & $5 \cdot 3$ \\
\hline
\end{tabular}

fractions revealed a single band for VCP1, suggesting that they had been purified to homogenicity (Figs 2 and 3 ). The molecular mass of VCP1 was approximately $33 \mathrm{kDa}$, which corresponded with that of Pr1, purified from Metarbizium anisopliae.

Enzymoblotting of culture filtrates and purified VCP1 and $\operatorname{Pr} 1$, with Suc-(Ala $)_{2}$-Pro-Phe-pNA, showed that chymotrypsin-like activity was greatest at pI 10 but weaker activity was detected in culture filtrates at lower $\mathrm{pI}$ values (Fig. 2). M. anisopliae had at least three clearly distinct chymotrypsin-like enzymes, the most alkaline ones of which were difficult to separate.

\section{Substrate specificity}

Of the three chymotrypsin substrates assayed, VCP1 preferred Suc-(Ala $)_{2}$-Pro-Phe-pNA as opposed to SucPhe-pNA or Bz-Tyr-pNA (Table 2), suggesting that an aromatic residue in the $\mathrm{P} 1$ position (Schechter \& Berger, 
Table 4. Effect of protease inhibitors on purified VCP1 and culture filtrates of $V c 10$

Residual activities were measured against Suc-(Ala $)_{2}$-Pro-PhepNA as the substrate. Ethanol-containing controls were used in the case of TPCK, pepstatin A and phenanthroline, and a 2propanol-containing control for PMSF. Activity in the absence of inhibitor was $0.16 \mathrm{U}$ (VCP1) and $0 \cdot 12 \mathrm{U}$ (culture filtrate). All values are means of duplicate assays and are expressed as percentage of the activities in the absence of inhibitor.

\begin{tabular}{|c|c|c|c|}
\hline \multirow[t]{2}{*}{ Inhibitor } & \multirow[t]{2}{*}{ Concn } & \multicolumn{2}{|c|}{ Activity (\%) of } \\
\hline & & VCP1 & $\begin{array}{l}\text { Culture } \\
\text { filtrate }\end{array}$ \\
\hline Bowman-Birk & $0.4 \mathrm{mg} \mathrm{ml}^{-1}$ & $104 \cdot 0$ & $117 \cdot 6$ \\
\hline \multirow[t]{2}{*}{ TEW } & $0.4 \mathrm{mg} \mathrm{ml}^{-1}$ & $77 \cdot 0$ & $84 \cdot 3$ \\
\hline & $1 \mathrm{mg} \mathrm{ml}^{-1}$ & $80 \cdot 5$ & $77 \cdot 7$ \\
\hline \multirow[t]{2}{*}{ CEW } & $0.4 \mathrm{mg} \mathrm{ml}^{-1}$ & $56 \cdot 2$ & $73 \cdot 2$ \\
\hline & $1 \mathrm{mg} \mathrm{ml}^{-1}$ & $67 \cdot 5$ & $84 \cdot 4$ \\
\hline \multirow[t]{2}{*}{ STI } & $0.4 \mathrm{mg} \mathrm{ml}^{-1}$ & $68 \cdot 3$ & $86 \cdot 0$ \\
\hline & $1 \mathrm{mg} \mathrm{ml}^{-1}$ & $52 \cdot 6$ & $85 \cdot 0$ \\
\hline \multirow[t]{2}{*}{ TPCK } & $10 \mu \mathrm{M}$ & $104 \cdot 9$ & $101 \cdot 6$ \\
\hline & $100 \mu \mathrm{M}$ & $25 \cdot 5$ & $91 \cdot 5$ \\
\hline \multirow[t]{2}{*}{ TLCK } & $10 \mu \mathrm{M}$ & $93 \cdot 0$ & $102 \cdot 7$ \\
\hline & $100 \mu \mathrm{M}$ & $89 \cdot 7$ & $81 \cdot 1$ \\
\hline PMSF & $1 \mathrm{mM}$ & 0.01 & 0 \\
\hline Eilastatinal & $250 \mu \mathrm{M}$ & $82 \cdot 3$ & $82 \cdot 4$ \\
\hline \multirow[t]{2}{*}{ Leupeptin } & $0 \cdot 1 \mathrm{mM}$ & $71 \cdot 9$ & $85 \cdot 8$ \\
\hline & $0.5 \mathrm{mM}$ & $67 \cdot 0$ & $81 \cdot 1$ \\
\hline Pepstatin A & $1 \mu \mathrm{M}$ & $85 \cdot 8$ & $80 \cdot 6$ \\
\hline E-64 & $10 \mu \mathrm{M}$ & $79 \cdot 7$ & $84 \cdot 5$ \\
\hline Phenanthroline & $10 \mathrm{mM}$ & $114 \cdot 2$ & $99 \cdot 7$ \\
\hline EDTA & $1 \mathrm{mM}$ & $68 \cdot 7$ & $76 \cdot 2$ \\
\hline
\end{tabular}

1967) was insufficient for hydrolysis. VCP1 also exhibited weak trypsin, elastase and subtilisin-like activity since it was able to hydrolyse Bz-Phe-Val-Arg-pNA, Suc-(Ala) 3 $^{-}$ pNA and CBZ-(Ala) ${ }_{2}$-Leu-pNA, respectively (Table 2). The trypsin substrate Bz-Arg-pNA was not degraded. Substrate specificity of VCP1 and proteases in culture filtrate was similar, presumably because VCP1 accounted for most of the non-specific protease activity (Table 2).

The specific activity of VCP1 for $1 \mathrm{mM} \mathrm{Suc-(Ala)})_{2}$-ProPhe-pNA $\left(19 \cdot 2 \mathrm{U} \mathrm{mg}^{-1}\right)$ was approximately a third of that of bovine chymotrypsin $\left(53.6 \mathrm{U} \mathrm{mg}^{-1}\right)$, but more than 60 times greater than that of porcine elastase for this substrate (Table 2). Porcine pancreatic elastase hydrolysed both elastase [Suc-(Ala $)_{3}$-pNA, MeOSuc-(Ala $)_{2}$-Pro-Val$\mathrm{pNA}$ ] and chymotrypsin [Suc-(Ala $)_{2}$-Pro-Phe-pNA] substrates (Table 2). The specific activity of both VCP1 and porcine elastase for Suc-(Ala $)_{3}$ - - NA was low (Table $2)$. VCP1, in contrast to the commercial proteases tested, was able to hydrolyse CBZ-(Ala) ${ }_{2}$-Leu-pNA albeit weakly (Table 2), suggesting that it may belong to the subtilisin superfamily of serine proteases.

Both VCP1 and the commercial proteases degraded a wide range of protein substrates to varying degrees (Table
Table 5. Chymoelastase and non-specific protease activity of different Verticillium species

Chymoelastase and non-specific protease activities measured using Suc-(Ala $)_{2}$-Pro-Phe-pNA, and Azocoll, respectively. Activities are expressed relative to those from $V c 10$. The maximum chymotrypsin-like and Azocoll degrading activities corresponding to $100 \%$ were $0.40 \mathrm{U}$ and $16.2 \mathrm{U}$, respectively. Units of activity for the nitroanalide are $\mu \mathrm{mol} \mathrm{min}^{-1}$, one unit of activity for hydrolysis of Azocoll is increase in $A_{520}$ of 0.001 absorbance unit $\mathrm{min}^{-1}$.

\begin{tabular}{|c|c|c|c|}
\hline Species & Isolate & $\begin{array}{c}\text { Chymotrypsin- } \\
\text { like } \\
\text { activity } \\
(\% \text { of } V c 10)\end{array}$ & $\begin{array}{c}\text { Non-specific } \\
\text { protease } \\
\text { activity } \\
(\% \text { of } V c 10)\end{array}$ \\
\hline \multirow[t]{5}{*}{$V$. chlamydosporium } & $V c 8$ & $96 \cdot 6$ & $82 \cdot 8$ \\
\hline & $V c 10$ & 100 & 100 \\
\hline & $V c 26$ & $23 \cdot 3$ & $30 \cdot 8$ \\
\hline & $V c 65$ & $23 \cdot 6$ & $70 \cdot 9$ \\
\hline & $V c 11$ & 0.5 & $6 \cdot 1$ \\
\hline \multirow[t]{3}{*}{$V$. lecanii } & $V l G$ & $18 \cdot 0$ & $33 \cdot 3$ \\
\hline & $V l M y$ & $32 \cdot 7$ & $86 \cdot 1$ \\
\hline & $V / 4$ & $23 \cdot 2$ & $38 \cdot 9$ \\
\hline$V$. albo-atrum & & $0 \cdot 1$ & 0 \\
\hline$V$. dabliae & & $0 \cdot 3$ & $1 \cdot 5$ \\
\hline
\end{tabular}

3). VCP1 was highly active against Azocoll and hide azure, and moderately active against casein, albumin and elastin. Activity of proteases from culture filtrates on azocasein and azoalbumin appeared to be greater than that of the purified VCP1, presumably because different enzymes were acting on these substrates (Table 3).

\section{Kinetic properties}

The reaction of VCP1 with Suc-(Ala $)_{2}$-Pro-Phe-pNA had a Michaelis-Menten constant, $K_{\mathrm{m}}$, of $4.26 \times 10^{-5} \mathrm{M}$, which coincides exactly with the $K_{\mathrm{m}}$ value for bovine chymotrypsin and this substrate (Del Mar, 1979). The catalytic constant, $k_{\text {cat }}$, was determined as $5.77 \mathrm{~s}^{-1}$ and the specificity constant, $k_{\text {cat }} / K_{\mathrm{m}}$, was $1.35 \times 10^{5} \mathrm{M}^{-1} \mathrm{~s}^{-1}$.

\section{Inhibitors}

Thirteen protease inhibitors were tested for their effect on the activity of VCP1 and the culture filtrate (Table 4). The serine protease inhibitor PMSF completely inhibited VCP1 and all proteolytic activity in culture filtrates. Tosyl-Phe-chloromethyl ketone (TPCK; chymotrypsin inhibitor), which has affinity for histidyl groups (Shaw et al., 1965), was effective at $100 \mu \mathrm{M}$, causing $75 \%$ inhibition of VCP1 and $8.5 \%$ inhibition of culture filtrates. Similarly, the residual activity of VCP1 was less than that of the culture filtrates in the presence of leupeptin, chicken eggwhite inhibitor containing ovoinhibitor (CEW) and STI (Table 4). 

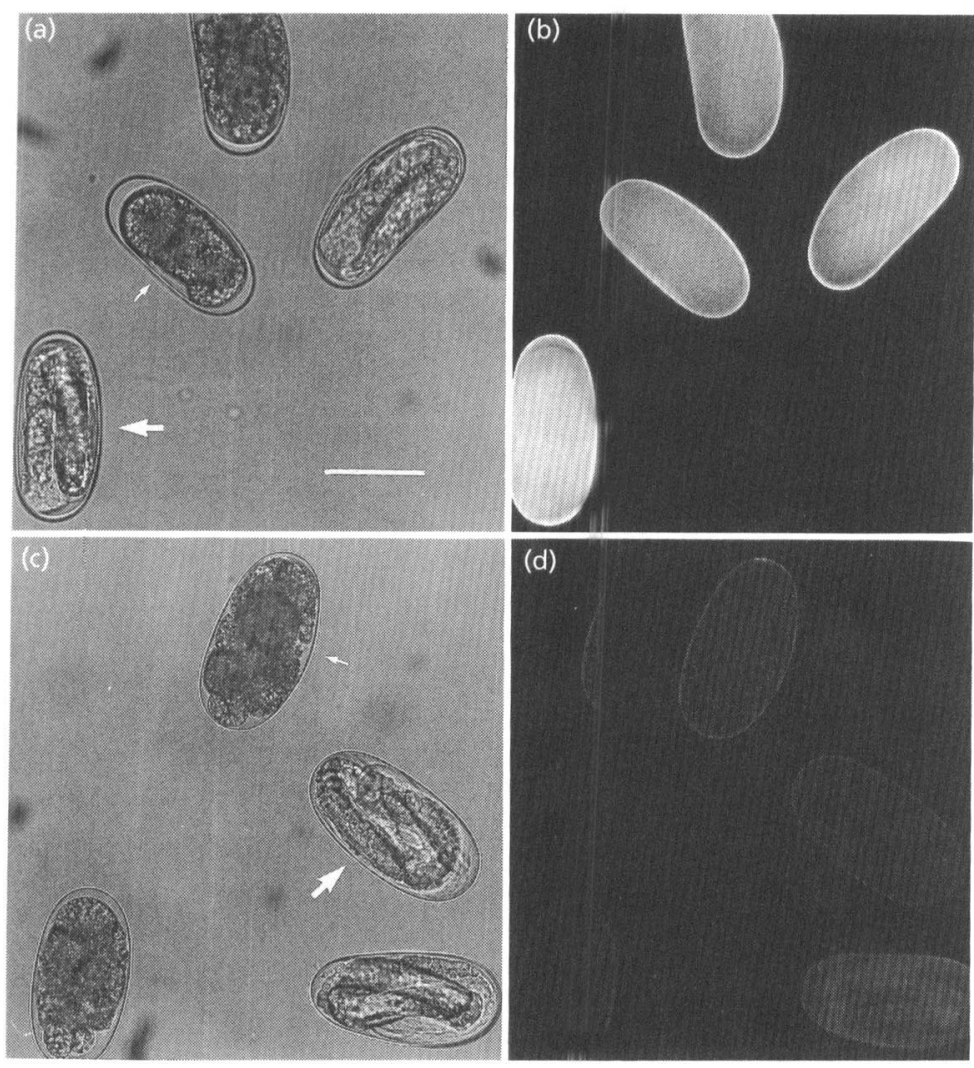

Fig. 4. Photomicrographs of $M$. incognita eggs stained with Calcofluor white $M 2 R$ and treated with $0.2 \mathrm{UVCP} 1$ for $18 \mathrm{~h}$, recorded in bright field (a) and violet light (b), and eggs treated with the same amount of heatdenatured VCP1 in bright field (c) and violet light (d). Small arrows point at an immature egg; large arrows point at a mature egg. Bar, $20 \mu \mathrm{m}$.

\section{VCP1 and non-specific protease activity of other Verticillium spp.}

The proteolytic activity in culture filtrates of five $V$. chlamydosporium isolates ( $\left.V c 8, V_{c} 10, V_{c} 26, V_{c} 65, V_{c 11}\right)$ differed significantly, with $V c 10$ and $V c 11$ exhibiting maximum and minimum activity, respectively (Table 5). In Vc10, VCP1 activity accounted for the bulk of the nonspecific protease activity but this was not the case for all isolates (e.g. Vc65, VIMy). Both non-specific protease and chymotrypsin-like activities of $V$. lecanii $(18-33 \%$ ) were consistently lower than $V c 10$ and were almost absent in $V$. albo-atrum and $V$. dabliae (Table 5).

\section{Effect of VCP1 on host nematode egg shells}

Protein and chitin are main structural components of nematode egg shells, chitin being covered by protein (Clarke et al., 1967; Bird \& McClure, 1976). The soluble protein content of the supernatant of $M$. incognita eggs treated with purified VCP1 was $60 \mu \mathrm{g} \mathrm{ml}^{-1}$, whereas eggs treated with the same amount of denatured protease gave an average reading of $31 \mu \mathrm{g} \mathrm{ml}^{-1}$ (one-way ANOVA, $F=9.51, \quad P=0.037$ ), indicating that the protease hydrolysed proteins from the nematode eggs. The removal of the protein cover from the eggs shells was further evidenced by staining similarly treated eggs for chitin with Calcofluor, resulting in very low background fluorescence in the eggs incubated in denatured protease (Fig. 4d), but bright blue fluorescence in VCP1 treated eggs (Fig. 4b). This suggested that the underlying chitin fibrils had been exposed. Eggs contained embryos in various developmental stages (Fig. 4a,c), but the fluorescence intensity of the egg shells was indiscriminately uniform (Fig. 4b, d).

\section{DISCUSSION}

VCP1, a major alkaline protease secreted by $V$. chlamydosporium $(V c 10)$ in soya peptone medium, was purified from culture filtrates to homogeneity using preparative IEF. The enzyme shared several characteristics with $\operatorname{Pr} 1$, a major protease secreted by the insect pathogen Metarbizium anisopliae (St Leger et al., 1987a). These included similar charge (pI approx. 10), size (approx. $33 \mathrm{kDa}$ ), sensitivity to PMSF and the ability to hydrolyse chymotrypsin and elastase substrates. However, VCP1 was less sensitive to CEW and TEW inhibitors (St Leger et al., 1987a) but more sensitive to TPCK. Furthermore, VCP1 had a greater affinity for Suc(Ala) $)_{2}$-Pro-Phe-pNA than Pr1, but a smaller catalytic constant, although the specificity constant for this substrate was similar. These observations suggest that VCP1 is a chymoelastase similar but not identical to Pr1. An extracellular serine protease of $V$. suchlasporium has a size of $32 \mathrm{kDa}$, which is similar to VCP1, but its preliminary characterization (Lopez-Llorca, 1990) does not allow a fair comparison.

This paper provides the first clear evidence of a chymoelastase-like enzyme in a nematophagous fungus. Other hyphomycete fungi also produce alkaline chymoelastase-like enzymes, including Beawveria bassiana, $V$. lecanii, Nomuraea rileyi, Aschersonia aleyrodis (St Leger et 
al., 1987b) and Paecilomyces farinosus (Samuels et al., 1990). Antibodies against the chymoelastase Pr1 from $M$. anisopliae cross-react only with enzymes from some isolates of the same species (St Leger et al., 1987b) but more sensitive assays have demonstrated that the basic proteases of B. bassiana, $P$. fumosoroseus and $M$. anisopliae share common epitopes (Shimizu et al., 1993).

It is clear from this study that different isolates of $V$. chlamydosporium produce different amounts of chymoelastase, which corroborates the findings of $\mathrm{St}$ Leger et al. (1987b) for $V$. lecanii. The absence of such activity in plant-pathogenic members of the genus Verticillium suggests that this particular enzyme is restricted to invertebrate pathogens. These observations support the proposition of St Leger et al. (1987b) that these enzymes are required by invertebrate pathogens for nutrition, and as this paper shows, this would include the nematophagous fungus $V$. chlamydosporium. However, the overall success of fungal pathogens is dependent upon a complex interaction of several factors (Charnley \& St Leger, 1991), including host recognition and the production of the right set and quantity of enzymes (Butt, 1990). In this respect VCP1 can be seen as a potent but broad-spectrum protease that not only has the potential to provide the facultative parasite $V$. chlamydosporium with nutrients from a wide range of protein sources, but may also have a role in pathogenesis, as it dissolves the outer protein barrier from $M$. incognita eggs.

\section{ACKNOWLEDGEMENTS}

We are grateful to Bio-Rad for providing the Rotofor isoelectric focusing cell. R.S. acknowledges receipt of a research studentship from the EC ECLAIR programme.

\section{REFERENCES}

Bieth, J., Spiess, B. \& Wermuth, C. G. (1974). The synthesis and analytical use of a highly sensitive and convenient substrate of elastase. Biochem Med 11, 350-357.

Bird, A. F. \& McClure, M. A. (1976). The tylenchid (Nematoda) egg shell: structure, composition and permeability. Parasitology 72, 19-28.

Bjerrum, O. J. \& Schafer-Nielsen, C. (1986). Buffer systems and transfer parameters for semi-dry electroblotting with a horizontal apparatus. In Electrophoresis '86, pp. 315-327. Edited by M. J. Dunn. Weinheim: VCH.

Bradford, M. M. (1976). A rapid and sensitive method for quantitation of microgram quantities of protein utilizing the principle of protein-dye binding. Anal Biochem 72, 248-254.

Bundy, H. F. (1962). A new spectrophotometric method for the determination of chymotrypsin activity. Anal Biochem 3, 431-435.

Butt, T. M. (1990). Fungal infection processes - a mini-review. Vth International Colloquium for Invertebrate Pathology Adelaide, pp. 121-124. Society for Invertebrate Pathology.

Butt, T. M., Hoch, H. C., Staples, R. C. \& St Leger, R. J. (1989). Use of fluorochromes in the study of fungal cytology and differentiation. Exp Mycol 13, 303-320.

Carder, J. H., Segers, R., Butt, T. M., Barbara, D. J., Von Mende, N. \& Coosemans, J. (1993). Taxonomy of the nematophagous fungi $\checkmark$ erticillium chlamydosporium and $V$. suchlasporium based on secreted enzyme activities and RFLP analysis. J Invert Pathol 62, 178-184.
Charnley, A. K. \& St Leger, R. J. (1991). The role of cuticledegrading enzymes in fungal pathogenesis in insects. In The fungal spore and disease initiation in plants and animals, pp. 267-286. Edited by G. T. Cole \& H. C. Hoch. New York: Plenum Press.

Chavira, R. Jr, Burnett, T. J. \& Hageman, J. H. (1984). Assaying proteinases with Azocoll. Anal Biochem 136, 446-450.

Clarke, A. J., Cox, P. M. \& Shepherd, A. M. (1967). The chemical composition of the egg shells of the potato cyst-nematode, Heterodera rostocbiensis Woll. Biochem J 104, 1056-1060.

Dackman, C. (1990). Fungal parasites of the potato cyst nematode Globodera rostocbiensis: isolation and reinfection. J Nematol 22, 594-597.

Dackman, C., Chet, I. \& Nordbring-Hertz, B. (1989). Fungal parasitism of the cyst nematode Heterodera schachtii: infection and enzymatic activity. FEMS Microbiol Lett 62, 201-208.

De Leij, F. A. A. M. (1992). The significance of ecology in the development of Verticillium chlamydosporium as a biological control agent against rootknot nematodes (Meloidogyne spp.). PhD thesis, Landbouwuniversiteit Wageningen.

Del Mar, E. G., Largman, C., Brodrick, J. W. \& Geokas, M. C. (1979). A new sensitive substrate for chymotrypsin. Anal Biochem 99, 316-320.

Erlanger, B. F., Kokowski, N. \& Cohen, W. (1961). The preparation and properties of two new chromogenic substrates of trypsin. Arch Biochem Biophys 95, 271-278.

Frosco, M., Chase, T. Jr \& Macmillan, J. D. (1992). Purification and properties of the elastase from Aspergillus fumigatus. Infect Immun 60, $728-734$.

Huang, J., Kim, J., Ramamurthy, P. \& Jones, T. H. D. (1992). The purification, specificity, and role of dipeptidyl peptidase III in Dictyostelium discoideum. Exp Mycol 16, 102-109.

Jackson, C. W., Heale, J. B. \& Hall, R. A. (1985). Traits associated with virulence to the aphid Macrosiphoniella sanborni in eighteen isolates of Verticillium lecanii. Ann Appl Biol 106, 39-48.

Kerry, B. R. \& Crump, D. H. (1977). Observations on fungal parasites of females and eggs of the cereal cyst-nematode, Heterodera avenae, and other cyst nematodes. Nematologica 23, 193-201.

Kerry, B. R., Crump, D. H. \& Mullen, L. A. (1982). Studies of the cereal cyst-nematode, Heterodera avenae under continuous cereals, 1974-1978. II. Fungal parasitism of nematode females and eggs. Ann Appl Biol 100, 489-499.

Kunert, J., Zemek, J., Augustín, J. \& Kuniak, L. (1987). Proteolytic activity of ovicidal soil fungi. Biologia (Bratislava) 42, 695-705.

Kwon-Chung, K. J., Lehman, D., Good, C. \& Magee, P. T. (1985). Genetic evidence for role of extracellular proteinase in virulence of Candida albicans. Infect Immun 49, 571-575.

Laemmli, E. K. (1970). Cleavage of structural proteins during the assembly of the head of bacteriophage T4. Nature 227, 680-685.

Leatherbarrow, R. J. (1990). Using linear and non-linear regression to fit biochemical data. Trends Biochem Sci 15, 455-458.

Lopez-Llorca, L. V. (1990). Purification and properties of extracellular proteases produced by the nematophagous fungus Verticillium suchlasporium. Can J Microbiol 36, 530-537.

Lopez-Llorca, L. V. \& Robertson, W. M. (1992). Immunocytochemical localization of a $32-\mathrm{kDa}$ protease from the nematophagous fungus Verticillium sucblasporium in infected nematode eggs. Exp Mycol 16, 261-267.

Morgan-Jones, G., Godoy, G. \& Rodriguez-Kabana, R. (1981). Verticillium chlamydosporium, fungal parasite of Meloidogyne arenaria females. Nematropica 11, 115-120.

Morgan-Jones, G., White, J. F. \& Rodriguez-Kabana, R. (1983). 
Phytonematode pathology: ultrastructural studies. I. Parasitism of Meloidogyne arenaria eggs by Verticillium chlamydosporium. Nematropica 13, 245-260.

Nagel, W., Willig, F., Peschke, W. \& Schmidt, F. H. (1965). Über die Bestimmung von Trypsin und Chymotrypsin mit Aminosäure-pnitroaniliden. Hoppe Seyler's Z Pbysiol Chem 340, 1-10.

Nakajima, K., Powers, J. C., Ashe, B. M. \& Zimmerman, M. (1979). Mapping the extended substrate binding site of cathepsin $G$ and human leukocyte elastase. J Biol Chem 254, 4027-4032.

Ohlsson, B. G., Westrom, B. R. \& Karlsson, B. W. (1986). Enzymoblotting: a method for localizing proteinases and their zymogens using para-nitroanalide substrates after agarose gel electrophoresis and transfer to nitrocellulose. Anal Biochem 152, 239-244.

Paris, S. \& Feron, P. (1979). Study of the virulence of some mutants of Beauveria brogniartii. J Invert Patbol 34, 71-77.

Perry, R. N. \& Trett, M. W. (1986). Ultrastructure of the eggshell of Heterodera schachtii and Heterodera glycines. Rev Nématol 9, 399-403.

Pichuantes, S., Babe, L. M., Barr, P. J. \& Craik, C. S. (1989). Recombinant HIV1 protease secreted by Saccharomyces cerevisiae correctly processes myristylated gag polyprotein. Proteins: Struct Funct Genet 6, 324-337.

Samuels, R. I., Charnley, A. K. \& St Leger, R. J. (1990). The partial characterisation of endoproteases and exoproteases from three species of entomopathogenic entomophthorales and two species of deuteromycetes. Mycopathologia 110, 145-152.

Schechter, I. \& Berger, A. (1967). On the size of the active site in proteases. I. Papain. Biochem Biophys Res Commun 27, 157-162.

Shaw, E., Mares-Guia, M. \& Cohen, W. (1965). Evidence for an active-center histidine in trypsin through use of a specific reagent, 1-chloro-3-tosylamido-7-amino-2-heptanone, the chloromethyl ketone derived from $\mathrm{N}^{\alpha}$-tosyl-L-lysine. Biochemistry 4, 2219-2224.
Shimizu, S., Tsuchitani, Y. \& Matsumoto, T. (1993). Serology and substrate specificity of extracellular proteases from four species of entomopathogenic hyphomycetes. J Invert Pathol 61, 192-195.

Sijmons, P. C., Grundler, F. M. W., Von Mende, N., Burrows, P. \& Wyss, U. (1991). Arabidopsis thaliana as a new model host for plantparasitic nematodes. Plant J 1, 245-254.

St Leger, R. J., Charnley, A. K. \& Cooper, R. M. (1986). Cuticledegrading enzymes of entomopathogenic fungi: synthesis in culture on cuticle. $J$ Invert Pathol 48, 85-95.

St Leger, R. J., Charnley, A. K. \& Cooper, R. M. (1987a). Characterization of cuticle-degrading proteases produced by the entomopathogen Metarbizium anisopliae. Arch Biochem Biophys 253, 221-232.

St Leger, R. J., Cooper, R. M. \& Charnley, A. K. (1987b). Distribution of chymoelastases and trypsin-like enzymes in five species of entomopathogenic Deuteromycetes. Arch Biochem Biopbys 258, 123-131.

St Leger, R. J., Durrands, P. K., Charnley, A. K. \& Cooper, R. M. (1988). The role of extracellular chymoelastase in the virulence of Metarbizium anisopliae for Manduca sexta. J Invert Pathol 52, 285-294.

Stepanov, V. M., Strongin, A. Y., Izotova, L. S., Abramov, Z. T., Lyublinskaya, L. A., Ermakova, L. M., Baratova, L. A. \& Belyanova, L. P. (1977). Intracellular serine protease from Bacillus subtilis. Structural comparison with extracellular serine proteases subtilisins. Biochem Biophys Res Commun 77, 298-305.

Svendsen, L., Blombäck, B, Blombäck, M. \& Olsson, P. I. (1972). Substrates for determination of trypsin, thrombin and thrombinlike enzymes. Folia Haematol (Leipz) 98, 446-454.

Willcox, J. \& Tribe, H. T. (1974). Fungal parasitism in cysts of Heterodera. I. Preliminary investigations. Trans Brit Mycol Soc 62, 585-594.

Received 28 April 1994; revised 23 May 1994; accepted 25 May 1994. 